\title{
Optimization of C\&D waste management by the application of Life Cycle Assessment (LCA) methodology: the case of the Municipality of Rome, Italy
}

\author{
F. La Marca \\ Department of Chemical Engineering Materials Environment, \\ University of Rome "La Sapienza", Italy
}

\begin{abstract}
In recent years, in Italy, a large quantity of construction and demolition (C\&D) waste has been generated: in the year 2004 a production of about 46,0 Mt of C\&D waste has been estimated. After mechanical treatment, this waste can be recovered and recycled as secondary raw material, determining economic and environmental benefits, by reducing landfill, transportation and primary resources consumption. To date, the recycling rate of C\&D waste in Italy is only $10 \%$, due to the amount of recycled product. This study is aimed at carrying out an analysis of C\&D waste flow, in the Municipality of Rome, Italy, considering both the amount properly disposed or recycled, and the amount illegally dumped on the territory or in the containers for municipal solid waste. Furthermore, application of the Life Cycle Assessment (LCA) methodology has been applied in order to optimize C\&D waste recycling, considering the environmental impact connected to different C\&D waste management schemes. Data obtained from the LCA methodology allowed one to quantify the environmental performance, to estimate the costs of each scheme considered, and finally to evaluate the best C\&D waste management.
\end{abstract}

Keywords: C\&D waste, waste management, recycling, LCA.

\section{Introduction}

In many countries, construction and demolition (C\&D) waste generation has been increasing over the past decade, due to social and economic factors, such as population increase and rapid growth of towns and cities. 
Despite recycling becoming a consolidated issue, landfilling and, even worse, illegal dumping are still widespread practice.

The European Union, in the framework of the Sixth Environment Action Programme [1], in accordance with the EU Waste Strategy, has established that it is necessary to take action to improve the efficiency in C\&D waste management, since the annual quantity generated exceeds 450 million tonnes, while the percentage of material recovery is only $25 \%$ [2].

Several European countries have implemented a national policy to encourage preventing production and promoting reuse, recycling and recovery of C\&D waste in accordance to EU waste hierarchy [3-8].

\section{The C\&D waste}

C\&D waste is composed of different typologies of materials, in variable percentage, depending on waste source, construction technologies, building characteristics, local raw materials. An average composition in weight of C\&D waste in Italy is reported in Table 1 [9].

Table 1: $\quad$ Average composition of C\&D waste in Italy.

\begin{tabular}{cc}
\hline Waste category & $\% \mathrm{wt}$ \\
\hline Concrete & 30,0 \\
\hline not reinforced concrete & 10,0 \\
\hline reinforced concrete & 20,0 \\
\hline bricks (tile, perforated brick, etc.) & 50,0 \\
\hline asphalt & 5,0 \\
\hline excavated ground & $6,0-10,0$ \\
\hline paper and cardboard & $0,6-4,0$ \\
\hline metals & 3,0 \\
\hline others & $1,0-1,4$ \\
\hline
\end{tabular}

The C\&D waste production derives mainly from building renovation by private citizens, which generates small amounts of waste to be recovered or disposed of. Sometimes, the distance from the construction site to the recycling or disposal plants favours illegal waste disposal.

In the Northern Europe, the highest levels of recovery and/or recycling of C\&D waste are found (Table 2), firstly due either to a shortage in natural resources, either to a well-established environmental culture. Secondly, the imposition of political measures, such as taxation and restrictive rules on waste disposal, aimed at reducing landfilling of recoverable materials, has led to the increase in reusing secondary raw materials from C\&D waste and, on the other hand, to lower the exploitation of primary raw materials from quarrying.

In comparison with Northern Europe, in Italy, the recovery of C\&D waste is strongly limited by the abundance of affordable natural resources and by a diffuse and unchecked illegality in C\&D waste disposal. 
Table 2: Production, recovered/recycled and landfilled C\&D waste in Europe [10].

\begin{tabular}{|c|c|c|c|c|c|}
\hline & production & recovery & ycling & lanc & ing \\
\hline Country & $\mathrm{Mt} / \mathrm{yr}$ & $\mathrm{Mt} / \mathrm{yr}$ & $\%$ & $\mathrm{Mt} / \mathrm{yr}$ & $\%$ \\
\hline Germany & 59,00 & 10,03 & 17 & 48,97 & 83 \\
\hline UK & 30,00 & 13,50 & 45 & 16,50 & 55 \\
\hline France & 23,60 & 3,54 & 15 & 20,06 & 85 \\
\hline Italy & 20,00 & 1,80 & 9 & 18,20 & 91 \\
\hline Spain & 12,8 & 1,13 & 8,8 & 11,67 & 91,2 \\
\hline Netherlands & 11,17 & 10,17 & 91 & 1 & 9 \\
\hline Belgium & 6,75 & 6,19 & 92 & 0,56 & 8 \\
\hline Austria & 4,70 & 1,93 & 41 & 2,77 & 59 \\
\hline Greece & 1,80 & 0,07 & 4 & 1,73 & 96 \\
\hline Portugal & 3,20 & 0,13 & 4 & 3,07 & 96 \\
\hline Denmark & 2,64 & 2,22 & 84 & 0,42 & 16 \\
\hline Sweden & 1,69 & 0,64 & 38 & 1,05 & 62 \\
\hline Finland & 1,35 & 0,93 & 69 & 0,42 & 31 \\
\hline Ireland & 0,57 & 0,01 & 1 & 0,56 & 99 \\
\hline Luxembourg & 0,30 & 0,05 & 17 & 0,25 & 83 \\
\hline Total UE & 179,57 & 52,34 & 29 & 127,23 & 71 \\
\hline
\end{tabular}

To promote the recovery of C\&D waste against landfilling (all the more so against illegal landfilling), actions should be taken to relieve the pressures on disposal spaces as well as respecting the hierarchy of waste management.

\section{The case study}

The aim of this study is to optimise the management of C\&D waste flow in the municipality of Rome, Italy, in order to facilitate recovery/recycling and to minimise the environmental impacts due to $\mathrm{C} \& \mathrm{D}$ waste transportation.

In particular, a different scheme of transportation from construction sites inside the city to recycling/disposal sites has been analysed, in order to improve materials recovery and to reduce heavy traffic in the metropolitan area.

The amount of C\&D waste production is proportional to the construction site size. The widest ones, which produce large amounts of waste, can use trucks with great carrying capacity and optimise the transport. On the other hand, the smallest construction sites, which produce lower amounts of waste, utilise vehicles with a small truckload. As a consequence, the impact on metropolitan traffic is considerable, because of the numerous heavy transports inside the city.

The exact determination of C\&D waste production in the city of Rome is quite difficult for the following reasons:

- the latest official data on waste disposal are related to the year 2006 [11], based on the so-called MUD, a formal declaration on waste production carried out by waste producers in Italy; 
- after a national legislative decree (D.Lgs. 152/2006), the producers of nonhazardous waste are non obligated to the formal declaration;

- the most part of C\&D waste derives from the activity of small property developers, often operating without legal permission, increasing outlaw waste disposal.

A general assessment of C\&D waste production in Italy has been made by ANPAR (Associazione Nazionale Produttori di Aggregati Riciclati, a national association among producers of recycled aggregate), differentiated in Northern, Central and Southern Italy, analysing the amount of C\&D waste conferred to recycling plants. The productivity rate of $C \& D$ waste in Central Italy has been set to $510 \mathrm{~kg} / \mathrm{yr}$ per inhabitants [12].

The C\&D waste production (Table 3 ) in the city of Rome can be estimated considering the resident population (census at 31/12/2008).

Table 3: $\quad$ Estimated total C\&D waste production in the city of Rome.

\begin{tabular}{ccc}
\hline $\begin{array}{c}\text { productivity rate of C\&D waste } \\
\text { t/inhabitants } * \text { year }\end{array}$ & $\begin{array}{c}\text { inhabitants } \\
\text { at } 31 / 12 / 2008\end{array}$ & $\begin{array}{c}\text { C\&D waste production } \\
t\end{array}$ \\
\hline 0,51 & 2.811 .609 & 1.433 .921 \\
\hline
\end{tabular}

The main part of such C\&D waste production derives from so-called microdemolition, due to residential and non-residential renovation, which accounts altogether for $92 \%$ of the total C\&D waste, (Bressi [12], refers 53\% residential, $39 \%$ non-residential) (Table 4). The production from micro-demolition is responsible for heavy transport in the city area and for illegal dumping.

Table 4: Estimated C\&D waste production from micro-demolition in the city of Rome.

\begin{tabular}{ccc}
\hline Total & \multicolumn{2}{c}{ From micro-demolitions } \\
$t$ & $\%$ & $t$ \\
\hline 1.433 .921 & 92 & 1.319 .207 \\
\hline
\end{tabular}

Such production can be divided into the 20 administrative districts, defined within the metropolitan area, in relation to the inhabitants of each district (Table 5).

\subsection{Assessment of the current scheme of C\&D waste transportation}

The current scheme of C\&D waste transportation from micro-demolitions in the Municipality of Rome is represented in Figure 1. The C\&D waste produced by micro-demolitions has to be transferred from the city area to the recycling or disposal plants, generally located out of the metropolitan area (Figure 2).

The transport is usually made with 3,5-t vehicles (maximum payload: $2 \mathrm{t}$ ) because of the small amount of material to be moved. It is can be divided into three parts: 
Table 5: Distribution of C\&D waste production from micro-demolition in each city district of the city of Rome.

\begin{tabular}{|c|c|c|}
\hline City district & inhabitants & $\begin{array}{c}\text { C\&D waste produced } \\
t\end{array}$ \\
\hline 1 & 126.703 & 59.449 \\
\hline 2 & 122.785 & 57.611 \\
\hline 3 & 53.361 & 25.037 \\
\hline 4 & 199.771 & 93.733 \\
\hline 5 & 178.587 & 83.793 \\
\hline 6 & 123.373 & 57.887 \\
\hline 7 & 121.993 & 57.239 \\
\hline 8 & 224.672 & 105.416 \\
\hline 9 & 126.630 & 59.415 \\
\hline 10 & 181.929 & 85.361 \\
\hline 11 & 135.852 & 63.742 \\
\hline 12 & 171.650 & 80.538 \\
\hline 13 & 216.515 & 101.589 \\
\hline 15 & 150.876 & 70.791 \\
\hline 16 & 142.011 & 66.632 \\
\hline 17 & 70.459 & 33.059 \\
\hline 18 & 135.100 & 63.389 \\
\hline 19 & 181.645 & 85.228 \\
\hline 20 & 147.697 & 69.299 \\
\hline total & 2.811 .609 & 1.319 .207 \\
\hline
\end{tabular}

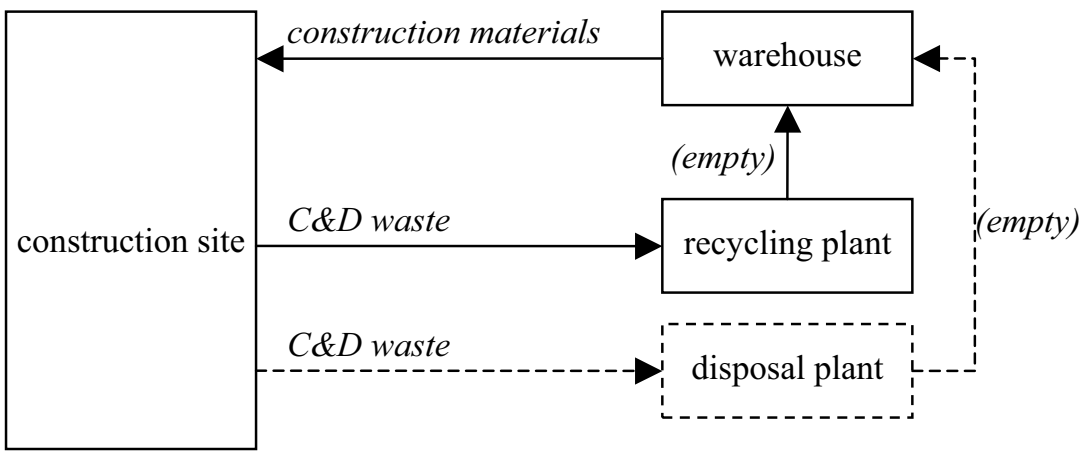

alternative route

Figure 1: Flowchart of the current scheme of C\&D waste transportation in the Municipality of Rome. 


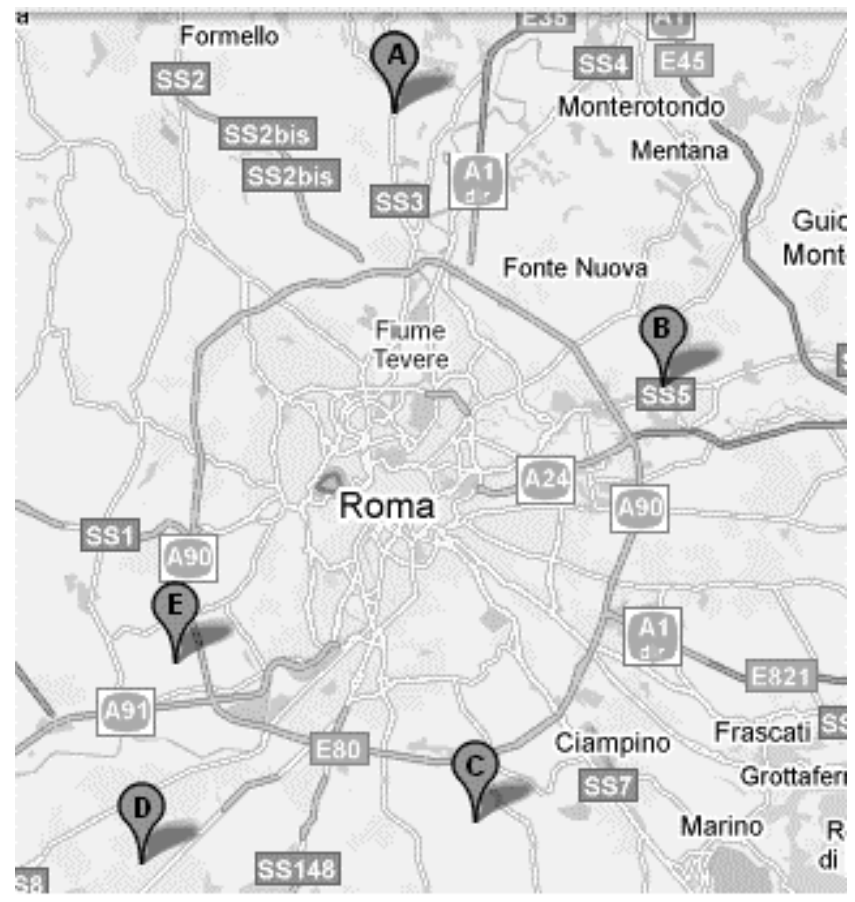

Figure 2: Location of recycling and disposal plants in the Municipality of Rome.

1) firstly, the vehicle moves from the construction site to the recycling or disposal plant, where C\&D waste is unloaded;

2) then, the vehicle usually proceeds to the warehouse in order to freight construction materials;

3) finally, the vehicle returns to the construction site.

For each city district, the distance between the barycentre (where construction sites are supposed to be) and the nearest recycling (or disposal) plant has been calculated (Table 6), while an average distance of $4 \mathrm{~km}$ has been considered between recycling (or disposal) plants and warehouses, which are quite disseminated in and out of the city area.

Under these hypotheses, the total kilometres per year currently covered for C\&D waste transportation can be calculated, as reported in Table 7.

\subsection{Assessment of an alternative scheme of C\&D waste transportation}

An alternative scheme of C\&D waste transportation from micro-demolitions in the Municipality of Rome is proposed, as represented in Figure 3. In this case, the $\mathrm{C} \& \mathrm{D}$ waste produced by micro-demolitions has to be transferred by 3,5-t vehicles from the city area to the nearest warehouse, quite disseminated within be divided into two stocks: recoverable and non-recoverable. Then, when an 
Table 6: Distances (city district barycentre - nearest recycling/disposal plant).

\begin{tabular}{ccc}
\hline City district & Recycling or disposal plant & distance $(\mathrm{km})$ \\
\hline I & E & 16,7 \\
\hline II & A & 20,1 \\
\hline III & B & 16,0 \\
\hline IV & A & 19,7 \\
\hline V & B & 10,2 \\
\hline VI & B & 12,0 \\
\hline VII & B & 11,2 \\
\hline VIII & B & 10,7 \\
\hline IX & C & 17,0 \\
\hline X & C & 15,3 \\
\hline XI & C & 13,2 \\
\hline XII & C & 10,1 \\
\hline XIII & D & 10,8 \\
\hline XV & E & 10,6 \\
\hline XVI & E & 13,1 \\
\hline XVII & E & 15,0 \\
\hline XVIII & E & 13,1 \\
\hline XIX & A & 18,4 \\
\hline XX & A & 20,2 \\
\hline
\end{tabular}

adequate amount of C\&D waste is cumulated, the transportation to the recycling plant (or to the disposal plant of non-recoverable waste) can be made by 44-t vehicles. In this way, the longest distance to the recycling (or disposal) plant is covered by large full-load vehicles.

Nineteen operating warehouses have been chosen, with suitable characteristics to serve as C\&D waste stock, conveniently distributed within the city area. In Table 8 the average distances between the barycentre of each city district (where construction sites are supposed to be) and the warehouse are reported.

The C\&D waste is collected in containers, $5,8 \times 2,5 \times 1,2 \mathrm{~m}$ in size, net volume equal to $10 \mathrm{~m}^{3}$ (gross volume equal to $17 \mathrm{~m}^{3}$ ). Considering a specific weight of $1,7 \mathrm{t} / \mathrm{m}^{3}$ and a filling rate of $90 \%$, the total net weight of the container is about $15 \mathrm{t}$ (gross weight equal to $16 \mathrm{t}$ ). Taking into consideration the weight limit of $44 \mathrm{t}$ for truck circulation, each truck transports 2 containers, that is $30 \mathrm{t}$ net C\&D waste.

Under these hypotheses, the total kilometres per year currently covered for C\&D waste transportation can be calculated, as reported in Tables 9 and 10 . 
Table 7: Kilometres per year currently covered for C\&D waste transportation.

\begin{tabular}{|c|c|c|c|c|c|}
\hline City district & $\begin{array}{c}\text { C\&D waste } \\
t / y r\end{array}$ & $\begin{array}{c}\text { distance } \\
\mathrm{km}\end{array}$ & $\begin{array}{c}\text { route length } \\
\mathrm{km}\end{array}$ & $\begin{array}{l}\text { \# journeys } \\
\text { per year }\end{array}$ & $\begin{array}{c}\text { total } \mathrm{km} \\
\mathrm{km} / \mathrm{yr}\end{array}$ \\
\hline I & 59.449 & 16,7 & 37,4 & 29.725 & 1.111 .697 \\
\hline II & 57.611 & 20,1 & 44,2 & 28.805 & 1.273 .197 \\
\hline III & 25.037 & 16,0 & 36,0 & 12.518 & 450.666 \\
\hline IV & 93.733 & 19,7 & 43,4 & 46.866 & 1.987 .130 \\
\hline $\mathrm{V}$ & 83.793 & 10,2 & 24,4 & 41.897 & 980.378 \\
\hline VI & 57.887 & 12,0 & 28,0 & 28.943 & 839.356 \\
\hline VII & 57.239 & 11,2 & 26,4 & 28.620 & 755.556 \\
\hline VIII & 105.416 & 10,7 & 25,4 & 52.708 & 1.286 .076 \\
\hline IX & 59.415 & 17,0 & 38,0 & 29.707 & 1.099 .174 \\
\hline $\mathrm{X}$ & 85.361 & 15,3 & 34,6 & 42.681 & 1.476 .747 \\
\hline XI & 63.742 & 13,2 & 30,4 & 31.871 & 1.096 .358 \\
\hline XII & 80.538 & 10,1 & 24,2 & 40.269 & 1.014 .781 \\
\hline XIII & 101.589 & 10,8 & 25,6 & 50.794 & 1.401 .926 \\
\hline $\mathrm{XV}$ & 70.791 & 10,6 & 25,2 & 35.396 & 998.153 \\
\hline XVI & 66.632 & 13,1 & 30,2 & 33.316 & 1.172 .715 \\
\hline XVII & 33.059 & 15,0 & 34,0 & 16.530 & 595.069 \\
\hline XVIII & 63.389 & 13,1 & 30,2 & 31.694 & 957.173 \\
\hline XIX & 85.228 & 18,4 & 40,8 & 42.614 & 1.738 .648 \\
\hline XX & 69.299 & 20,2 & 44,4 & 34.650 & 1.538 .447 \\
\hline total & 1.319 .207 & & & 659.603 & 21.773 .248 \\
\hline
\end{tabular}

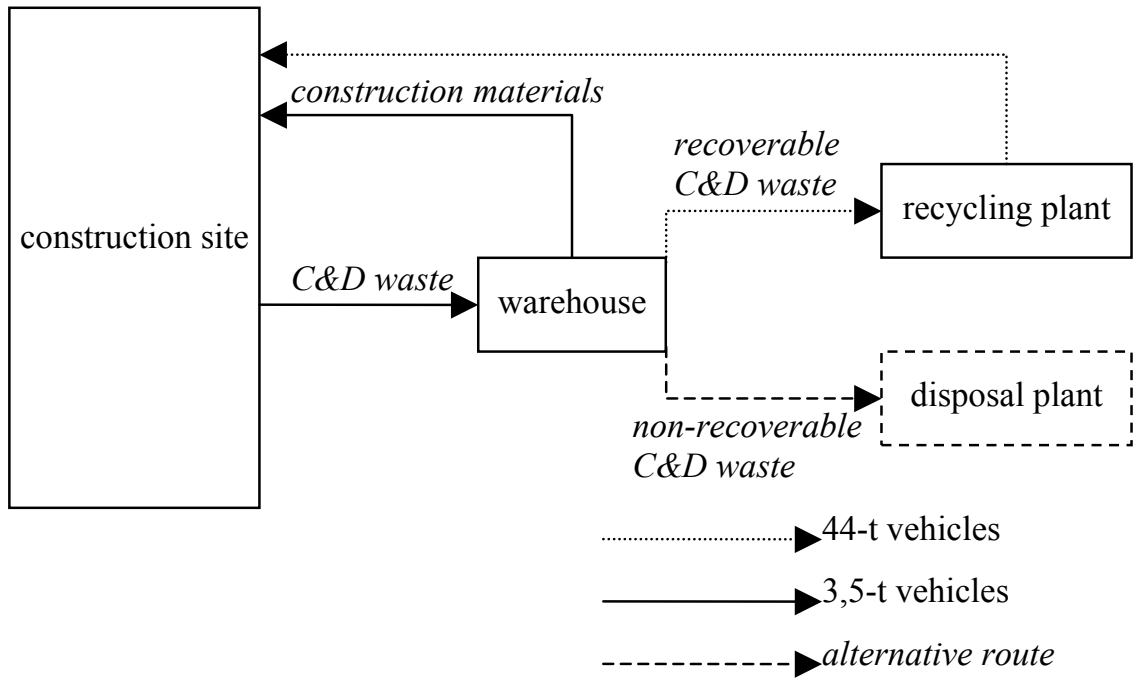

Figure 3: Flowchart of the alternative scheme of C\&D waste transportation in the Municipality of Rome. 
Table 8: $\quad$ Distances (city district barycentre - nearest warehouse).

\begin{tabular}{cc}
\hline City district & distance $(\mathrm{km})$ \\
\hline I & 4 \\
II & 4 \\
\hline III & 4 \\
IV & 3 \\
\hline V & 3 \\
VI & 5 \\
VII & 4 \\
\hline VIII & 3 \\
\hline IX & 3 \\
\hline X & 4 \\
\hline XI & 8 \\
\hline XII & 5 \\
\hline XIII & 6 \\
\hline XV & 7 \\
\hline XVI & 9 \\
\hline XVII & 6 \\
\hline XVIII & 4 \\
\hline XIX & 4 \\
\hline X & 4 \\
\hline
\end{tabular}

Table 9: $\quad$ Kilometres per year covered for C\&D waste transportation by 3,5-t vehicles in the alternative scheme.

\begin{tabular}{ccccc}
\hline City district & $\begin{array}{c}\text { C\&D waste } \\
t / y r\end{array}$ & $\begin{array}{c}\text { \# journeys } \\
\text { per year }\end{array}$ & $\begin{array}{c}\text { route length } \\
k m\end{array}$ & $\begin{array}{c}\text { total km } \\
k m / y r\end{array}$ \\
\hline I & 59.449 & 29.725 & 8 & 237.800 \\
\hline II & 57.611 & 28.805 & 8 & 230.440 \\
\hline III & 25.037 & 12.518 & 8 & 100.144 \\
\hline IV & 93.733 & 46.866 & 6 & 281.196 \\
\hline V & 83.793 & 41.897 & 6 & 251.382 \\
VI & 57.887 & 28.943 & 10 & 289.430 \\
\hline VII & 57.239 & 28.620 & 8 & 228.960 \\
\hline VIII & 105.416 & 52.708 & 6 & 316.248 \\
\hline IX & 59.415 & 29.707 & 6 & 178.242 \\
\hline X & 85.361 & 42.681 & 8 & 341.448 \\
\hline XI & 63.742 & 31.871 & 16 & 509.936 \\
\hline XII & 80.538 & 40.269 & 10 & 402.690 \\
\hline XIII & 101.589 & 50.794 & 12 & 609.528 \\
\hline XV & 70.791 & 35.396 & 14 & 495.544 \\
\hline XVI & 66.632 & 33.316 & 18 & 599.688 \\
\hline XVII & 33.059 & 16.530 & 12 & 198.360 \\
\hline XVIII & 63.389 & 31.694 & 8 & 253.552 \\
\hline XIX & 85.228 & 42.614 & 8 & 340.912 \\
\hline XX & 69.299 & 34.650 & 8 & 277.200 \\
\hline total & 1.319 .207 & 659.603 & & 6.142 .700 \\
\hline
\end{tabular}


Table 10: Kilometres per year covered for C\&D waste transportation by 44-t vehicles in the alternative scheme.

\begin{tabular}{|c|c|c|c|c|}
\hline City district & $\begin{array}{c}\text { C\&D waste } \\
t / y r\end{array}$ & $\begin{array}{l}\text { \# journeys } \\
\text { per year }\end{array}$ & $\begin{array}{c}\text { route length } \\
\mathrm{km}\end{array}$ & $\begin{array}{c}\text { total } \mathrm{km} \\
\mathrm{km} / \mathrm{yr}\end{array}$ \\
\hline I & 59.449 & 1.982 & 16,7 & 33.099 \\
\hline II & 57.611 & 1.920 & 20,1 & 38.592 \\
\hline III & 25.037 & 835 & 16,0 & 13.360 \\
\hline IV & 93.733 & 3.124 & 19,7 & 61.543 \\
\hline V & 83.793 & 2.793 & 10,2 & 28.489 \\
\hline VI & 57.887 & 1.930 & 12,0 & 23.160 \\
\hline VII & 57.239 & 1.908 & 11,2 & 21.370 \\
\hline VIII & 105.416 & 3.514 & 10,7 & 37.600 \\
\hline IX & 59.415 & 1.980 & 17,0 & 33.660 \\
\hline$X$ & 85.361 & 2.845 & 15,3 & 43.529 \\
\hline $\mathrm{XI}$ & 63.742 & 2.125 & 13,2 & 28.050 \\
\hline XII & 80.538 & 2.685 & 10,1 & 27.119 \\
\hline XIII & 101.589 & 3.386 & 10,8 & 36.569 \\
\hline XV & 70.791 & 2.360 & 10,6 & 25.016 \\
\hline XVI & 66.632 & 2.221 & 13,1 & 29.095 \\
\hline XVII & 33.059 & 1.102 & 15,0 & 16.530 \\
\hline XVIII & 63.389 & 2.113 & 13,1 & 27.680 \\
\hline XIX & 85.228 & 2.841 & 18,4 & 52.274 \\
\hline XX & 69.299 & 2.310 & 20,2 & 46.662 \\
\hline total & 1.319 .207 & 43.974 & & 623.396 \\
\hline
\end{tabular}

\section{Application of the Life Cycle Assessment (LCA) methodology}

Life cycle assessment (LCA) is proposed as a technical tool for measuring impacts on the environment and their reduction, because by applying such approach, priorities can be identified more easily and policies can be targeted more effectively so that the maximum benefit for the environment is achieved relative to the effort expended [13].

The impact categories related to transportation emissions are:

- global warming, acidification and eutrophication due to $\mathrm{CO}, \mathrm{CO}_{2}, \mathrm{NO}_{\mathrm{x}}$ and particulate emissions in air;

- human health due to $\mathrm{CO}, \mathrm{CO}_{2}, \mathrm{NO}_{\mathrm{x}}$ and particulate emissions in air;

- natural resources depletion due to fuel consumption.

The total emissions per year are reported in Table 11, considering the current and the alternative scheme respectively. Adopting the Eco-indicator 99 method, the emissions have an impact on the ecosystem, measured by the Potentially Disappeared Fraction (PDF), on human health, evaluated by Disability-adjusted Life Years (DALY) and on natural resources depletion, measured in MJ [14]. The impact categories are weighted, assuming a priority factor (PF). Thus, for each indicator, an impact factors for $1 \mathrm{~kg}$ of substance have been considered 
Table 11: Total emissions per year for C\&D waste transportation in the current and the alternative scheme.

\begin{tabular}{cccccc}
\hline \multicolumn{7}{c}{ Current scheme } \\
\hline vehicle & $\mathrm{CO}$ & $\mathrm{CO}_{2}$ & $\mathrm{NO}_{\mathrm{x}}$ & particulate & fuel \\
& $\mathrm{kg}$ & $\mathrm{kg}$ & $\mathrm{kg}$ & $\mathrm{kg}$ & $\mathrm{kg}$ \\
\hline $3,5-\mathrm{t}$ & 18.398 & 6.314 .242 & 12.737 & 1.742 & 1.820 .244 \\
\hline \multicolumn{7}{c}{ Alternative scheme } \\
\hline $3,5-\mathrm{t}$ & 5.191 & 1.781 .380 & 3.593 & 491 & 513.529 \\
\hline 44-t & 4.264 & 1.270 .483 & 19.949 & 262 & 170.561 \\
\hline total & 9.455 & 23.542 & 23.542 & 753 & 684.090 \\
\hline
\end{tabular}

Table 12: $\quad$ Impact factors of considered indicators for $1 \mathrm{~kg}$ of substance.

\begin{tabular}{|c|c|c|c|c|c|c|}
\hline & $P F$ & $\mathrm{CO}$ & $\mathrm{CO}_{2}$ & $N O_{X}$ & particulate & fuel \\
\hline$P D F$ & 400 & & & $1,11 E-03$ & & \\
\hline$D A L Y$ & 400 & & $1,36 E-05$ & $5,76 E-03$ & & \\
\hline$M J$ & 200 & & & & & $7,02 E-04$ \\
\hline
\end{tabular}

Table 13: Ecopoints 99, referring to total emissions per year.

\begin{tabular}{lcccc}
\hline & Ecop/DALY & Ecop/PDF & Ecop/MJ & Ecop/Total \\
\hline current & 63.696 & 5.655 & 255.562 & 324.914 \\
\hline alternative & 70.843 & 10.453 & 96.046 & 177.342 \\
\hline$\%$ variation & $+11,22 \%$ & $+84,82 \%$ & $-62,41 \%$ & $-45,4 \%$ \\
\hline
\end{tabular}

(Table 12). The Ecopoints 99 (Table 13) give a synthetic evaluation of the impacts in the current and in the alternative transportation scheme, referring to total emissions per year.

In general a overall improvement in environmental impact is achieved by adopting the alternative transportation scheme. The Ecop/PDF worsening is due to the increasing of $\mathrm{NO}_{\mathrm{x}}$ emission from the 44-t vehicles. This result could be overcome by the application of the Euro 5 standards on emissions reduction, considering the restricted limits: $180 \mathrm{mg} / \mathrm{km}$ (20\% reduction of emissions in comparison to the Euro 4 standard).

\section{Conclusions}

The use of a LCA model for analysing two scenarios makes it possible to provide quantitative and qualitative information both on the overall and particular environmental performance. LCA can identify not only the best scenario, but also the analytical contribution of each emission operations to the overall environmental performance of the system.

In particular, in this case study, it has been possible to investigate how an alternative $\mathrm{C} \& \mathrm{D}$ waste transportation affected environmental impact. 


\section{References}

[1] European Community (EC), Sixth Environmental Action Programme of 2001 - 2010 (Sixth EAP). Environment 2010: Our Future, Our Choice. European Community, Brussels, Belgium, 2001.

[2] European Environmental Agency (EEA), Review of Selected Waste Streams. Technical Report No. 69. European Environmental Agency, Copenhagen, Denmark, 2002.

[3] Bulgarian Government - Ministry of Environment and Water (MOEW), National Strategy for the Environment and Action Plan 2000-2006. Bulgarian Ministry of Environment and Water, Sofia, Bulgaria, 1999.

[4] Spanish Government - Ministry of the Presidency, Real Decreto 105/2008, de 1 de Febrero, por el que se Regula la Producción y Gestión de los Residuos de Construcción y Demolición (National Decree 105/2008, February 1, which Regulates the Production and Management of Construction and Demolition Waste). Ministry of the Presidency, Madrid, Spain, 2008.

[5] United Kingdom Government - Department for Communities and Local Government, Code for Sustainable Homes. The Department for Communities and Local Government, London, United Kingdom, 2006.

[6] Buyle-Bodin, F., Organisation project for the reclamation of industrial wastes in the French North and Pas de Calais region. In: Proc. of Int. Rec. Congress ReC'93, vol. III. 19-22 January, Geneva, Switzerland, pp. 36-38, 1993.

[7] Ferguson, J., Kermode, N., Nash, C.L., Sketch, W.A.J., Huxford, R.P., Managing and Minimizing Construction Waste: A Practical Guide. Institution of Civil Engineers, London, United Kingdom, 1995.

[8] Hadjieva-Zaharieva, R., Dimitrova, E., Buyle-Bodin, F., Building waste management in Bulgaria: challenges and opportunities. Waste Management, 23, pp. 749-761, 2003.

[9] Arpa Liguria, Linee guida sui rifiuti speciali - Costruzione e demolizione (Guidelines on industrial waste: Construction and demolition waste), in Italian, 2007.

[10] European Commission, Report to DGXI, Construction and demolition waste management practices and their economic impacts, 1999.

[11] Ispra, Rapporto sui rifiuti, in Italian, 2008.

[12] Bressi, G., Elementi chiave del settore del riciclaggio dei rifiuti da costruzione. Proceedings of the Conference "Il riutilizzo dei rifiuti da costruzione e demolizione nelle infrastrutture”, 28 March 2002, Rome, A.N.P.A.R., in Italian, 2002.

[13] ISO, Environmental management - Life cycle assessment - Principles and framework. ISO 14040:2006. International Organization for Standardization, Geneve, Switzerland, 2006.

[14] Goedkoop M. and Spriensma R., The Eco-indicator 99: a damage oriented method for Life Cycle Impact Assessment - Methodology report, PRé Consultants, Amersfoort The Netherlands, 2001. 